\title{
Kardiologia prewencyjna w świetle najnowszych doniesień z Kongresu Europejskiego Towarzystwa Kardiologicznego w Barcelonie, 26-30 sierpnia 2017 roku
}

\author{
Preventive cardiology in the aspect of recent reports from the Congress \\ of the European Society of Cardiology in Barcelona, August 26-30, 2017
}

\author{
Błażej Michalski
}

Klinika Kardiologii Katedry Kardiologii Uniwersytetu Medycznego w Łodzi, Wojewódzki Szpital Specjalistyczny im. W. Biegańskiego

Ostatni Kongres Europejskiego Towarzystwa Kardiologicznego (ESC, European Society of Cardiology), który odbył się we wrześniu 2017 roku w Barcelonie, zdominowały ważkie doniesienia z zakresu kardiologii prewencyjnej zawierające wyniki dużych badań klinicznych - co rzadkie w ostatnich latach - zakończonych pozytywnymi wynikami. W niniejszym sprawozdaniu zaprezentowano cztery istotne badania, które mogą istotnie wpłynąć na jakość i długość życia pacjentów obciążonych podwyższonym ryzykiem sercowo-naczyniowym.

Leki przeciwpłytkowe pozwalają obniżyć ryzyko powikłań u wielu pacjentów z chorobami zależnymi od miażdżycy. Rola doustnych antykoagulantów nowej generacji jest słabiej poznana w tym zakresie zastosowań. Ważne dane przyniosło randomizowane, przeprowadzone metodą podwójnie ślepej próby badanie COMPASS (Cardiovascular Outcomes for People Using Anticoagulation Strategies), w którym oceniano korzyści za skojarzonej terapii kwasem acetylosalicylowym (ASA, acetylsalicylic acid) i riwaroksabanem we wtórnej prewencji sercowo-naczyniowej [1]. Włączono do niego liczną grupę ponad 23 tys. pacjentów ze stabilną chorobą wieńcową albo zmianami miażdżycowymi w tętnicach obwodowych. Pacjenci zostali podzieleni na trzy grupy w zależności od stosowanego leczenia, tj. terapii skojarzonej riwaroksabanem $\mathrm{w}$ dawce $2,5 \mathrm{mg}$ $2 \mathrm{razy} /$ dobe + ASA w dawce $100 \mathrm{mg} /$ dobe, monoterapii riwaroksabanem $5 \mathrm{mg} 2$ razy /dobę lub monoterapią ASA w dawce $100 \mathrm{mg} /$ dobę. Pacjentów oceniano pod kątem wystąpienia złożonego punktu końcowego, obejmującego zgon z przyczyn sercowo-naczyniowych, zawał serca i udar mózgu. Badanie zostało przedwcześnie przerwane, ponieważ wykazano zdecydowaną korzyść z terapii skojarzonej riwaroksabanem w dawce $2,5 \mathrm{mg} 2$ razy/dobę z ASA pod względem występowania złożonego punktu końcowego. W grupie przyjmującej riwaroksaban z ASA zdarzenia te występowały o $24 \%$ rzadziej niż u pacjentów przyjmujących sam ASA $(4,1 \%$ v. 5,4\%, współczynnik ryzyka [HR, hazard ratio $]=0,76 ; 95-$ proc. przedział ufności $[\mathrm{Cl}$, confidence interval] $0,66-0,86 ; p<0,001$ ). W przypadku monoterapii riwaroksabanem wykazano nieco mniejszą liczbę powikłań krążeniowych (o 10\%) i nie osiągnęła ona znamienności statystycznej w porównaniu z ASA. Nie stwierdzono istotnego statystycznie obniżenia ryzyka zgonu ogółem między grupami przyjmującą riwaroksaban z ASA a leczoną samym ASA $(3,4 \%$ v. $4,1 \%, \mathrm{HR}=0,82 ; 95 \% \mathrm{Cl} 0,71-0,96 ; p=$ $=0,01$ ), jednak ryzyko zgonu z przyczyn krążeniowych obniżyło się o 24\%. Zaobserwowano, zgodnie z przypuszczeniami, nadwyżkę epizodów krwawienia w grupie poddanej terapii skojarzonej (były one o 51\% częstsze także w u osób poddanych monoterapii riwaroksabanem) w porównaniu z grupą leczoną tylko ASA (3,1\% v. 1,9\%, HR $=1,7 ; 95 \%$ Cl 1,4-2,05; $p<0,001$ ), przy czym najczęstsze krwawienia dotyczyły przewodu pokarmowego. Nie stwierdzono jednak znamiennego wzrostu ryzyka najgroźniejszych krwawień wewnątrzczaszkowych. Samoistne krwotoki wewnątrzczaszkowe były rzadkie, choć nieco częstsze w przypadku stosowania terapii skojarzonej, która z kolei obniżała ryzyko udaru niedokrwiennego wtórnie ukrwotocznionego w porównaniu z ASA oraz wybitnie skuteczniej chroniła przed udarem niedokrwiennym. Przyjmowanie riwaroksabanu $w$ dawce $5 \mathrm{mg} 2$ razy/dobę nie zmieniało zatem rokowania w porównaniu z ASA, wiążąc się z wyższym ryzykiem istotnych klinicznie krwawień (wzrost ryzyka wobec ASA o 34\% dla monoterapii $2 \times 5 \mathrm{mg}$ ), natomiast

Adres do korespondencji: dr n. med. Błażej Michalski, Klinika Kardiologii, Katedra Kardiologii Uniwersytetu Medycznego w Łodzi, Wojewódzki Szpital Specjalistyczny im. W. Biegańskiego, ul. Kniaziewicza 1/5, 91-347 Łódź, e-mail: bwmichalski@op.pl 
schemat ASA $100 \mathrm{mg}$ i riwaroksaban 2 razy $2,5 \mathrm{~m}$ g wydaje się zapowiadać nowy standard leczenia przeciwzakrzepowego. W dyskusji zwrócono uwagę na fakt, że zastosowanie proponowanej, skuteczniejszej terapii u 10\% populacji pacjentów z chorobą wieńcową lub miażdżycą tętnic obwodowych pozwoliłoby zapobiec 100 tys. zgonów i 250 tys. powikłań krążeniowych w skali globu.

Mimo obecnie obowiązujących standardów intensywnego leczenia w prewencji wtórnej aż 40\% pacjentów po przebytym zawale serca z powodu nasilenia procesów miażdżycowo-zapalnych pozostaje w grupie ryzyka ponownego wystąpienia zawału , udaru mózgu bądź zgonu z przyczyn krążeniowych W tej grupie osóbpodczas 5-letniej obserwacji stwierdzono, że aż u 1/4 występują niepożądane zdarzenia sercowo-naczyniowe.

Kanakinumab to przeciwzapalny lek biologiczny, przeciwciało monoklonalne przeciwko interleukinie $1 \beta-$ kluczowej cytokinie uczestniczącej w procesie zapalnym indukowanym przez interleukinę 6 , który może umożliwić stłumienie niekorzystnego odczynu zapalnego zwiększającego ryzyko powikłań krążeniowych. W przeprowadzonym metodą podwójnie ślepej próby, randomizowanym badaniu CANTOS [2] (Canakinumab Antiinflammatory Thrombosis Outcome Study) oceniano efekty dołączenia kanakinumabu do standardowej terapii u pacjentów po zawale serca. Analizowano częstość występowania niepożądanych zdarzeń sercowo-naczyniowych - udaru mózgu, zgonu z przyczyn krążeniowych bądź ponownego zawału [3].

Do badania włączono 10061 pacjentów po przebytym zawale serca oraz z nasilonym procesem zapalnym. Za kryterium nasilonego procesu zapalnego przyjęto stężenie wysokoczułego białka C-reaktywnego (hsCRP, high-sensitivity C-reactive protein) większe lub równe $2 \mathrm{mg} / \mathrm{l}$. Chorzy otrzymywali pełne leczenie farmakologiczne zgodniee z aktualnymi wytycznymi - średni okres obserwacji wyniósł 3,7 roku. Średni wiek zakwalifikowanych pacjentów (25\% stanowiły kobiety) wynosił 61 lat, 37\% chorowało na cukrzycę, średnie stężenie hsCRP wynosiło 4,2 mg/l, a stężenie cholesterolu frakcji LDL (low-density lipoprotein) - $61 \mathrm{mg} / \mathrm{dl}$.

Pacjentom podawano kanakinumab (lub placebo) podskórnie co 3 miesiące, w trzech różnych dawkach - 50 mg, 150 mg i 300 mg. Randomizację dla dawek $150 \mathrm{mg}$ i $300 \mathrm{mg}$ przeprowadzono w stosunku do placebo $1: 1$, natomiast dla dawki $50 \mathrm{mg}-1,5: 1$. Oceniano częstość wystąpienia zawału serca, udaru mózgu bądź zgonu z przyczyn krążeniowych. Po 48 miesiącach obserwacji stężenie hsCRP obniżyło się o $26 \%$ w grupie przejmującej kanakinumab w dawce $50 \mathrm{mg}$, o 37\% w przypadku dawki $150 \mathrm{mg}$ i o 41\% w przypadku dawki300 mg. W ciągu obserwacji (3,7 roku) częstość występowania złożonego punktu końcowego wynosiła 4,5\% w grupie przyjmującej placebo, $4,11 \%$ - w grupie przyjmującej 50 mg kanakinumabu, $3,86 \%$ - w grupie otrzymującej 150 mg i 3,9\% - w grupie otrzymującej 300 mg. Współczynnik ryzyka u osób przyjmujących dawkę 50 mg w porównaniu z grupą przyjmującą placebo wynosił 0,93 (95\% Cl 0,8-1,07 p=0,3), u leczonych dawką $150 \mathrm{mg}$ wynosił 0,85 (95\% Cl 0,74-0,98; $p=0,021)$, natomiast u leczonych dawką $300 \mathrm{mg}-0,86$ (95\% Cl 0,75-0,99; $p=0,031)$, co oznacza znamiennie statystyczną korzyść ze stosowania dwóch większych dawek. Dawka 150 mg zapewniała także znamienne 17\% obniżenie ryzyka ponownej rewaskularyzacji w trybie pilnym (HR 0,83; 95\% Cl 0,73-0,95; $p=0,005$ ). Nie stwierdzono wpływu badanego leku na stężenie cholesterolu frakcji HDL (high-density lipoprotein) ani LDL, zaobserwowano wzrost stężenia triglicerydów o 5\%. Intrygującą obserwację stanowi zmniejszenie ryzyka wystąpienia niektórych nowotworów w grupie leczonej kanakinumabem. W grupie pacjentów przyjmujących kanakinumab zaobserwowano nieznacznie częstsze neutropenię, trombocytopenię oraz skłonność do infekcji. Wyniki badania CANTOS potwierdziły hipotezę, zgodnie z którą ograniczenie procesu zapalnego (istotne obniżenie stężenia hsCRP) wpływa na istotne zmniejszenie ryzyka chorób układu sercowo-naczyniowego u pacjentów po zawale serca, po raz pierwszy wykazano również możliwość ograniczenia ryzyka krążeniowego lekiem o izolowanym działaniu przeciwzapalnym.

Kolejną zakończoną sukcesem próbą było ogromne badanie REVEAL HPS-3/TIMI-55 (Randomized Evaluation of the Effects of Anacetrapib through Lipid-modification), w którym oceniano zastosowanie anacetrapibu w połączeniu z atorwastatyną u pacjentów ze zdiagnozowaną chorobą wieńcową [4]. Statyny są filarem prewencji schorzeń zależnych i miażdżycy, lecz nie u wszystkich pacjentów zapewniają uzyskanie bezpiecznych wartości lipidemii. Anacetrapib jest inhibitorem białka transportującego estry cholesterolu (CETP, cholesteryl ester transfer protein). Białko to umożliwia wymianę estrów cholesterolu między frakcją HDL a apolipoproteniami B o działaniu aterogennym. Mimo imponująco korzystnego wpływu na frakcje cholesterolu LDL i HDL, wcześniejsze badania z innymi inhibitorami CETP przerwano z powodu nasilenia niepożądanych zdarzeń sercowo-naczyniowych (torcetrapib) bądź braku skuteczności (dalcetrapib, ewacetrapib) po około 2 latach stosowania.

Celem badania była ocena terapii skojarzonej anacetrapibem i stosowaną wcześniej atorwastatyną u pacjentów ze zmianami miażdżycowymi w tętnicach wieńcowych. Analizowano częstość występowania zgonu z przyczyn krążeniowych, zawału sercu bądź konieczności rewaskularyzacji serca w 4-letnim okresie obserwacji, połączonych w złożony pierwotny punkt końcowy. Pacjenci przyjmowali atorwastatynę w dawce obniżającej stężenie cholesterolu całkowitego poniżej $135 \mathrm{mg} / \mathrm{dl}$, a frakcji LDL - poniżej $77 \mathrm{mg} / \mathrm{dl}$. To randomizowane badanie przeprowadzono metodą podwójnie ślepej próby. Pacjentom dodatkowo podawano $100 \mathrm{mg} /$ dobę anacetrapibu lub placebo z randomizacją 1:1. Do badania włączono 30449 pacjentów, 
których średni wiek wynosił 67 lat; 84\% stanowili mężczyźni, u $88 \%$ uczestników w wywiadzie stwierdzono chorobę wieńcową, u 22\% występowały zmiany w naczyniach ośrodkowego układu nerwowego, 37\% chorowało na cukrzyce. W momencie randomizacji, po 8 tygodniach obserwacji i przyjmowaniu adekwatnej dawki atorwastatyny średnia wartość stężenia cholesterolu frakcji LDL wynosiła $61 \mathrm{mg} / \mathrm{dl}$, natomiast cholesterolu frakcji HDL $-40 \mathrm{mg} / \mathrm{dl}$. W 4-letnim okresie obserwacji zdarzenia niepożądane wystąpiły znamiennie rzadziej w grupie pacjentów stosujących anacetrapib niż w grupie przyjmującej placebo $(10,8 \%$ v. 11,8\%; HR - 0,91; 95\% Cl 0,85-0,97; $p=0,004)$. W grupie otrzymującej ancetrapib stężenie cholesterolu frakcji HDL było wyższe o $43 \mathrm{mg} / \mathrm{dl}(1,12 \mathrm{mmol} / \mathrm{l})$, frakcji LDL - niższe o $11 \mathrm{mg} / \mathrm{dl}(-0,3 \mathrm{mmol} / \mathrm{l})$, cholesterolu frakcji nie-HDL - niższe o $17 \mathrm{mg} / \mathrm{dl}(0,44 \mathrm{mmol} / \mathrm{l})$ w porównaniu z grupą przyjmującą placebo. W badaniu REVEAL potwierdzono, że ryzyko występowania niepożądanych zdarzeń sercowo-naczyniowych u pacjentów z udokumentowanymi zmianami miażdżycowymi w tętnicach w trakcie intensywnej terapii atorwastatyną obniża się o 9\% w przypadku stosowania terapii skojarzonej z anacetrapibem. Ponadto zaobserwowano mniejszą zapadalność na cukrzycę w grupie leczonej anacetrapibem. Mimo umiarkowanej siły działania ochronnego trzeba podkreślić, że anacetrapib uzyskał je na tle intensywnej statynoterapii, mógłby zatem stanowić potencjalny składnik terapii skojarzonej bądź alternatywę dla pacjentów nietolerujących statyn.

Podstawą kardiologii prewencyjnej jest prozdrowotna modyfikacja stylu życia - w tym sposobu odżywiania się. Autorzy aktualnych zaleceń dietetycznych oparli je głównie na badaniach europejskich oraz północnoamerykańskich. Na tym tle dużym zaskoczeniem okazały się wyniki jednej $z$ analiz globalnego badania PURE (Prospective Urban Rural Epidemiology) dotyczące wpływu diety [5]. Włączono do niego ponad 135 tys. osób w wieku 35-75 lat w 18 krajach, przy średnim okresie obserwacji wynoszącym 7,4 roku. Oceniano występowanie pierwotnego punktu końcowego: śmiertelności całkowitej, zgonu z przyczyn sercowo-naczyniowych, zawału serca, udaru mózgu, wystąpienia niewydolności sercowo-naczyniowej. Podstawą badania były kwestionariusze służące szczegółowej ocenie składu diety. Do celów analizy badaną populację podzieIono na kwartyle w zależności od odsetkowych proporcji zaspokajania zapotrzebowania energetycznego przez określone składniki pokarmowe (węglowodany, tłuszcze, białko). W badanym okresie obserwacji zaobserwowano 5796 zgonów, przy czym 4784 były spowodowane powikłaniami ze strony układu sercowo-naczyniowego. Oceniano ryzyko wystąpienia złożonego punktu końcowego zaleźnie od przyjmowania węglowodanów, tłuszczów, poszczególnych rodzajów kwasów tłuszczowych i ryzyka sercowo-naczyniowego oraz śmiertelności całkowitej. Większe spożycie węglowodanów wiązało się z wyższym o $28 \%$ ryzykiem zgonu z jakiejkolwiek przyczyny (HR = 1,28; $95 \%$ Cl 1,12-1,46), natomiast spożycie tłuszczu korelowało z niższym ryzykiem śmiertelności całkowitej (HR 0,77; 95\% Cl 0,67-0,87; p < 0,0001). Większe spożycie tłuszczów nasyconych (HR 0,86 [0,76-0,99] p =0,0088), tłuszczów jednonasyconych (HR 0,81 [0,71-0,92]; $p<0,0001$ ) i tłuszczów wielonienasyconych (HR 0,80 [0,71-0,89]; $p<0,0001$ ) obniżało ryzyko zgonu z jakiekolwiek przyczyny. Większe spożycie tłuszczów nasyconych wiązało się z niższym ryzykiem udaru mózgu (HR 0,79 [95\% Cl 0,64-0,98]; $p=0,0498)$. Co ciekawe, spożycie tłuszczu całkowitego bądź różnych frakcji kwasów tłuszczowych nie wiązało się z ryzykiem wystąpienia zawału serca bądź zgonu z przyczyn sercowo-naczyniowych. W badaniu PURE przeprowadzonym w 18 krajach w dużej populacji potwierdzono, że dieta bogata w węglowodany (> 60\% zapotrzebowania energetycznego) wiąże się z niekorzystnym wpływem na śmiertelność całkowitą oraz zgon z przyczyn innych niż sercowo-naczyniowe. Dieta bogata w tłuszcze wiązała się, zaskakująco, z niższym ryzykiem zgonu z jakiejkolwiek przyczyny. Autorzy badania podkreślają, że może to wynikać z tego, że w przypadku dużego spożycia węglowodanów nasila się dyslipidemia, wzrasta stężenie triglicerydów, maleje stężenie cholesterolu frakcji HDL, zwiększają się stężenie apolipoproteiny B i stosunek apolipoprotein B/A1 - ten ostatni wskaźnik jest silnym predyktorem zawału serca. W badaniu PURE po raz pierwszy tak wyraźnie wykazano, że duże spożycie węglowodanów wiąże się z niekorzystnym wpływem na śmiertelność całkowitą, natomiast spożycie nasyconych i nienasyconych kwasów tłuszczowych obniża ryzyko zgonu z jakiejkolwiek przyczyny i wystąpienia udaru mózgu. Obserwacje te nie pozostaną bez wpływu na przyszłe zalecenia dotyczące prewencji kardiologicznej.

\section{Piśmiennictwo}

1. Eikelboom JW, Connolly SJ, Bosch J, et al. COMPASS investigators. Rivaroxaban with or without aspirin in stable cardiovascular disease. N Engl J Med. 2017; 377(14): 1319-1330, doi: 10.1056/ /NEJMoa1709118, indexed in Pubmed: 28844192.

2. Ridker PM. How common is residual inflammatory risk? Circ Res. 2017; 120(4): 617-619, doi: 10.1161/CIRCRESAHA.116.310527, indexed in Pubmed: 28209792.

3. Ridker PM, Everett BM, Thuren T, et al. CANTOS Trial Group. Antiinflammatory therapy with canakinumab for atherosclerotic disease. N Engl J Med. 2017; 377(12): 1119-1131, doi: 10.1056/NEJMoa1707914, indexed in Pubmed: 28845751.

4. Bowman L, Hopewell JC, Chen F, et al. HPS3/TIMI55-REVEAL Collaborative Group. Effects of anacetrapib in patients with atherosclerotic vascular disease. N Engl J Med. 2017; 377(13): 1217-1227, doi: 10.1056/NEJMoa1706444, indexed in Pubmed: 28847206.

5. Dehghan M, Mente A, Zhang X, et al. Associations of fats and carbohydrate intake with cardiovascular disease and mortality in 18 countries from five continents (PURE): a prospective cohort study. Lancet. 2017; 390(10107): 2050-2062, doi: 10.1016/S0140-6736(17)32252-3, indexed in Pubmed: 28864332. 